\title{
Study Determination About Receivers of Support for Rehabilitation "The Houses Unhabitable" in Slum Area, Indonesia
}

\author{
Boby Rahman ${ }^{1}$, Dhea Fina Ramadhanty ${ }^{1}$, Mohammad Agung Ridlo ${ }^{1}$ \\ 1) Urban Regional and Planning, Sultan Agung Islamic University, Semarang, Indonesia \\ Email : bobyrahman@unissula.ac.id
}

\begin{abstract}
Indonesia, a developing country, has launched a program with a target of 0\% slum in urban areas by 2020. It has been more than ten years since this program for handling urban slums has made many improvements. One aspect of the parameter that becomes an improvement in handling urban slum areas is the improvement of uninhabitable houses. This study investigates how the quality of urban slum settlements can be improved in the aspect of houses that are not habitable, especially in terms of determining the recipient of rehabilitation assistance for houses that are unhabitable in urban areas. This study used a qualitative methodology and analysis of the literature review in 21 scientific papers on selecting houses that are not habitable assistance and related regulations. The result is that there are two processes in determining Receivers of Support for Rehabilitation "The Houses Unhabitable", first through the aspects of the criteria for houses unhabitable which are technical in the field, and selection techniques that are more academic in nature. Aspects of the criteria for houses unhabitable provide an assessment of the area and buildings. whereas the selection technique requires a selection technique capable of managing data that has many criteria.

Keyword : Rehabilitation, Houses Unhabitable, Slum Area.
\end{abstract}

\section{Introduction}

The problem of uninhabitable houses has always been a major problem in urban areas. Based on BPS data for 2010 (Statistics Indonesia, 2010), there were 7.9 million uninhabitable houses units, of which 2.9 million were in urban areas and 5 million units were in rural areas. According to BPS RI statistics, most Indonesians build houses independently. A house built independently is a house built with the strength or ability of the community itself.

Article $28 \mathrm{H}$ of the Amendment to the 1945 Constitution mandates that the house is one of the basic rights that must be obtained by the people so that every citizen has the right to a good and healthy place to live and live environment. This statement is strengthened by Law Number 39 of 1999 concerning Human Rights Article 40 which states that everyone has the right to live and have a decent life. A house is a place for humans to carry out their lives. A house is also a place of refuge from the effects of climate and weather. Law Number 1 of 2011 concerning Housing and Settlement Areas, a house is a building that functions as a suitable place to live, a means of fostering family, a reflection of the dignity of its inhabitants, as well as assets for its owner.

The economic unpreparedness of citizens who build makeshift houses without proper or uninhabitable. Houses built independently are also a factor that makes residents live in uninhabitable houses. Habitable houses is a house that has met the standards and requirements for building safety and the minimum adequacy of the building area and the health of its occupants(Indonesian minister of settlements, 2008). Based on Law No.1 of 2011 concerning Housing and Settlement Areas, it mandates that the state is responsible for protecting the entire Indonesian nation through the implementation of housing and residential areas so that people are able to live and live in decent and affordable housing in healthy, safe, harmonious housing. and sustainable throughout Indonesia. For this reason, 
the Government continues to strive to protect the community so that they are able to live in a proper place. The government in improving the socioeconomic level of low-income people is shown by the social assistance programs for the community.

A large number of houses unfit for habitation in urban areas is partly due to the high cost of housing in urban areas. Settlement arrangements in urban areas need to be prepared so as not to incur other costs, such as the provision of drinking water, sanitation, and transportation. In 2020 , only $54.1 \%$ of households have the opportunity to be able to live in affordable and livable housing in cities (Ministry of Public Works and Public Housing of the Republic of Indonesia, 2020). The growth of unsuitable houses makes the problem of slum settlements still the main issue of the many polemic urban development problems. In fact, many efforts have been made to deal with slum settlements, but they are always directly proportional to the growth of new slum settlements in urban areas. Various efforts have been made by the government in handling slum areas with the RPJMN 2020-2045 in the Housing and Settlement Sector, namely increasing community access or facilities gradually to the provision of decent, safe and affordable housing and settlements to create an inclusive and livable city. It also aims to support the fulfillment of the MDG targets as well as the mandate of Law No.1 of 2011 concerning Housing and Settlement Areas as mentioned earlier.

The government continues to strive to improve and handle uninhabitable houses because of the threat to the system and order of urban life. The hope is that in 2024 there will be $70 \%$ of the target of households with decent \& affordable housing (Bappenas, 2020). For this reason, it is necessary to collect uninhabitable houses data as information for the Government to know which citizens in urban areas still inhabit uninhabitable houses. This is also the basis for determining the priority of recipients of housing rehabilitation assistance in targeted cities. With the aim of efficiency and effectiveness of the program, the Government urgently needs the uninhabitable houses database. The database needs to be updated, due to the fact that this uninhabitable house increases over time. For this reason, it is very important to do data collection on houses that are unfit for habitation. In determining proper houses and unsuitable houses, it is also necessary to pay attention to the characteristics and conditions of each house in urban areas.

To determine whether the house is suitable or unfit for habitation, of course, it is necessary to compile criteria for determining the uninhabitable houses. According to the latest uninhabitable houses data collection issued by the Ministry of PUPR in 2016, the criteria for uninhabitable have many versions of each related service/institution/agency. The following is a comparison table for uninhabitable houses indicators according to several other agencies/institutions/offices. The criteria for each service or institution and related institutions are of course based on the research that has been done. For this reason, a literature study approach was carried out to determine the determination of uninhabitable houses beneficiaries. The purpose of this research is to take a study approach to accurately determine the correct information to obtain uninhabitable houses assistance. In order to be able to provide a comprehensive study of how other regions have implemented a housing improvement program that is uninhabitable.

\section{Methods}

This study uses a literature review that discusses aid programs related to handlers for unsuitable housing and handlers located in Indonesia. Articles were searched through the google scholar engine search and found the number of relevant papers to discuss. 
Furthermore, the paper is discussed critically between papers to extract the essence of the discussion and learning related to receiving uninhabitable housing assistance which can be taken as a learning process.

\section{Results and Discussion}

\subsection{Uninhabitable Houses Receivers Acceptance Criteria}

The problem of providing livable houses for low-level communities is one of the problems. Various parties have made various house repair aids by establishing criteria as a standard for determining beneficiaries so that they are right on target. The criteria for receiving uninhabitable houses assistance are not more precise in considering the uninhabitable houses, economic conditions and legality (Ardiansyah et al., 2020; Arzian et al., 2020; Danik, 2014; Fauzi, 2016; Harianja \& Lumbantoruan, 2019; Irawan et al., 2018; Kuswandhie \& Primadasa, 2019; Mardiati \& Oktafianto, 2017; Mursyidin \& Rusdah, 2020; Nalatissifa \& Ramdhani, 2020; Puteri \& Notobroto, 2017; Satria \& Tambunan, 2020; Sevrianda \& Putri, 2018; Simatupang \& Wuryandari, 2016; Sundari et al., 2019; Tumanggor et al., 2018; Yetri, 2020). The characteristics of uninhabitable houses review comprehensively from the physical point of view of the house building, starting from the area of the building, walls, roofs, floors, building structures, foundations, types of houses, toilets, building lighting, clean water, distance from water and electricity sources. The characteristics of the uninhabitable houses are the most detailed characteristics of the assessment, the most have elements that must be assessed. However, some locations have a simpler and more physical assessment such as building area, walls, roofs, floors.

In the aspect of economic conditions, from the point of view of the ability of the homeowner to renovate the house, because the building is one of the indicators of a slum, then the repair of the building to improve the function of life and the aesthetics of the residential area needs to be improved. So that the economic aspect becomes important to support, whether the occupants are able to improve the condition of the building themselves or need assistance for its improvement. The parameters used in the assessment of the economic condition of the uninhabitable house owners are the burden of the burden (person in the family), poverty status, self-help readiness, type of work, stage, asset ownership, need for food assistance, and historical whether or not they have received assistance before.

The legality aspect of ownership examines the legal aspects of a house building. This aspect looks at the status of ownership and ownership. Ownership status is a review of two important aspects related to land ownership status and house buildings. Meanwhile, proof of ownership is the completeness of the status in the form of ownership of house and land certificates.

In certain cases, determining which houses to receive repair assistance is urgently needed because the number of uninhabitable houses budget allocations for the home improvement program is still limited. Then added other criteria that determine the determination, namely the determination of the level of slum areas(Mursyidin \& Rusdah, 2020). The slum level of this area is assessed in an area study and determined in regulation. So that buildings in areas that have a high level of turbidity will become a priority for receiving uninhabitable houses assistance.

\subsection{Selection Technique}

The number of uninhabitable houses, of course, it will require accuracy and data processing techniques with many criteria. If the criteria for housing aid recipients are uninhabitable houses, it is very technical in nature for buildings in the field, then the 
selection technique is closer to the academic approach. Based on the results of a literature study in selecting recipients of uninhabitable housing assistance in Indonesia, several selection techniques are used. The selection techniques are divided into three categorical techniques, the first is the selection technique, the weighting technique and the ranking technique. These three techniques can be used separately or together to determine beneficiaries according to criteria.

In the selection method, the selection of uninhabitable house receipts uses the FMDAM analysis technique and the SAW analysis technique method. FMDAM technique aims to determine the results of selecting each data alternative (Satria \& Tambunan, 2020). While the Simple Additive Weighting (SAW) method of analysis technique is used to determine decisions with many criteria, and to take into account every form of alternative data available(Arzian et al., 2020; Irawan et al., 2018; Mursyidin \& Rusdah, 2020). The two approaches to academia are carried out because these two approaches are suitable in selecting data with a large number of criteria, such as the criteria for uninhabitable houses.

In the weighting method, the method used is starting from the AHP, WSM, LVQ, SAW, and Smarter analysis methods. The Analytical Hierarchy Process (AHP) method is used to make decisions in calculating priority weights and consistency that meet the criteria (Kuswandhie \& Primadasa, 2019; Mardiati \& Oktafianto, 2017; Mursyidin \& Rusdah, 2020; Sundari et al., 2019). The Weight Sum Model (WSM) method is a method that is often used in weighting because it is the easiest to apply and has been applied in several locations for selecting uninhabitable housing assistance (Yetri, 2020). The LVQ and Naive Bayes methods are a valid way of determining uninhabitable Houses classification. LVQ is a method that is done by assigning a value to the layer of neurons, only the best neurons or in other words neurons with only visible values. Bayes is a simple probability-based prediction technique by performing the Naïve Bayes classification with the highest last probability from each class (Simatupang \& Wuryandari, 2016). The Simple Additive Weighting (SAW) method apart from being a selection, can be continued with weighting by calculating the criteria in order to get the weight of the ranking weight in supporting decision making (Arzian et al., 2020). Whereas in the SMARTER Method, it is also used to give weight to each criterion for determining aid recipients (Kuswandhie \& Primadasa, 2019).

In the ranking method, SAW, TOPSIS, Electree, Backpropagrion, AHP, WP, Vikor, and MEC analysis methods can be used. The Simple Additive Weighting (SAW) method is one of the analytical methods that are able to provide good input in terms of selection, weighting, and ranking in helping recipients of uninhabitable house repair assistance (Mursyidin \& Rusdah, 2020). Decisions are made using the Analytical Hierarchy Process (AHP) method to determine the middle to lower class population and those who are prioritized for receiving housing assistance (Mardiati \& Oktafianto, 2017). Weighted Product (WP) Is a decision-making method by means of multiplication to connect attribute ratings, where the rating of each attribute must be ranked first with the attribute weight imposed, the WP method is a supporting system for determining Uninhabitable Houses beneficiaries with a rank system (DANIK, 2014) The VIKOR method is a complex multicriteria method and can be seen from the ranking and selection of the criteria layout (Tumanggor et al., 2018). The MEC method is used to determine influential criteria such as stage, house walls, floors, type of house, building area, and roof of the house (Kuswandhie \& Primadasa, 2019). 


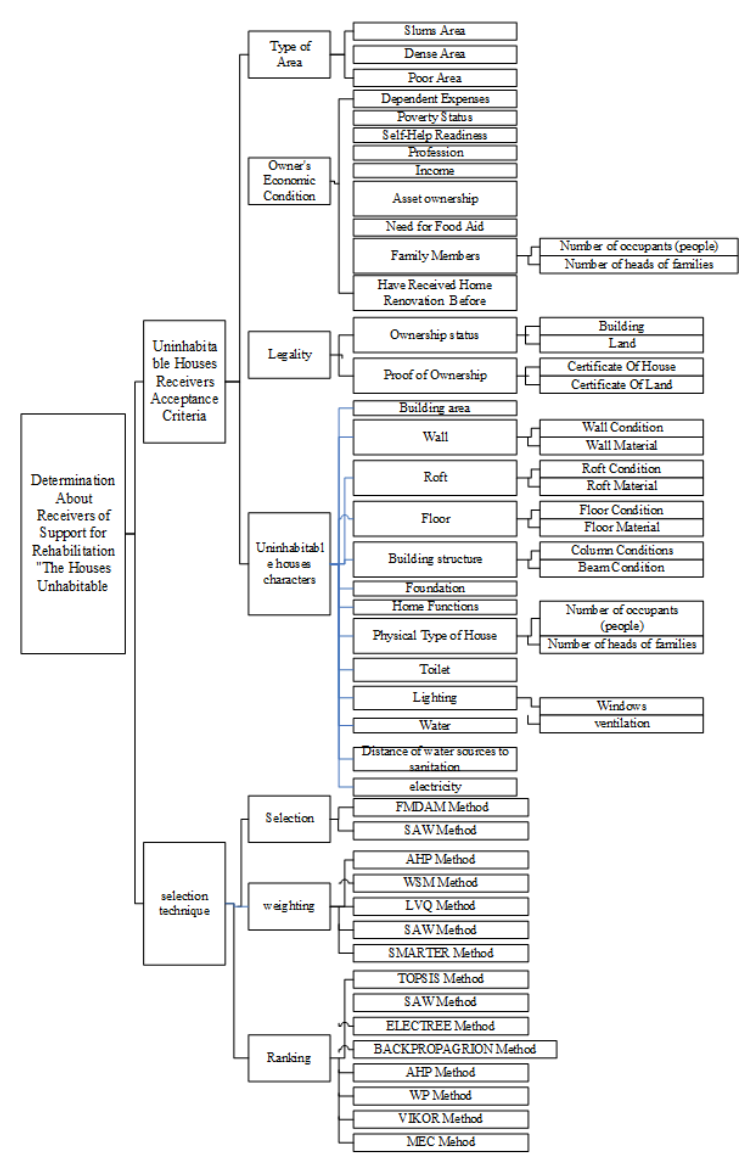

Figure 1. analysis results

\section{Conclusion}

Uninhabitable houses are an indicator of a slum area that must function as housing and aesthetics. Broadly speaking, there are two things that can be seen in determining the determination of housing assistance unfit for habitation, namely the criteria for housing criteria and the aspect of selection. Aspects of household criteria are determined from the uninhabitable houses criteria, economic conditions, legality plus the slum level aspects required due to scarcity. In the technical aspect of acceptance, three aspects can be used, namely the aspect of selection, weighting, and ranking. With these criteria, the typology of the selection technique used is a technique that has specifications on very large and complicated data. This research contributes to the considerations in the method of determining the priority of uninhabitable houses.

\section{References}

Ardiansyah, H., Junianto, M. B. S., \& Machfud, S. (2020). Sistem Penunjang Keputusan Penentuan Penerima Dana Bantuan Rumah Tidak Layak Huni Dengan Metode Smarter Dan Topsis Pada Desa Rawakalong. Jurnal SAINTEKOM, 10(1), 26. https://doi.org/10.33020/saintekom.v10i1.98

Arzian, R., Abidin, Z., Irfan, P., \& Yunus, M. (2020). Penerapan Fuzzy SAW untuk Rekomendasi Penentuan Penerima Bantuan Pembangunan Rumah Tidak Layak Huni (Application of Fuzzy SAW for Recommendations on Determining Recipients of 
Development Assistance The House is Not Livable ). Jurnal Teknologi Informasi Dan Multimedia, 2(1), 36-42.

Bappenas. (2020). Arah Kebijakan Pembangunan Perkotaan Dan Permukiman Sebelum Dan Pada Era Normal Baru. Bappenas.

Danik, K. (2014). Sistem Pendukung Keputusan Penerima Bantuan Rumah Layak Huni Dengan Menggunakan Metode Weighted Product (WP). In Udinus. Udinus.

Fauzi, W. (2016). Sistem Pendukung Keputusan Penerima Bantuan Dana Rutilahu dengan Menggunakan Metode Electre. Seminar Nasional Teknologi Informasi Dan Komunikasi 2016 (SENTIKA 2016), 2016(Sentika), 432-439.

Harianja, E. J. G., \& Lumbantoruan, G. (2019). Penerapan Metode TOPSIS dalam Menentukan Penerima Bantuan Bedah Rumah Pada Dinas Perumahan Dan Kawasan Permukiman Kabupaten Deli Serdang. Jurnal Times, 8(1), 29-38.

Indonesian minister of settlements. (2008). Regulation Indonesian minister of settlements 22/2008 abut Minimum Service Standards (SPM) in the Field of Public Housing in Provinces and Districts / Cities. Indonesian minister of settlements.

Irawan, H., Sabardi, W., \& Nadya, Y. (2018). Pendekatan Mcdm Dengan Metode Simple Additive Weighting (SAW) Untuk Model Penentuan Prioritas Penerima Rumah Bantuan Dinas Sosial. SEMNASTEK UISU, 1(1), 251-256.

Kuswandhie, R., \& Primadasa, Y. (2019). Penggabungan Metode MEC dan AHP dalam Penentuan Bantuan Rumah Tidak Layak Huni. Techno.Com, 18(2), 134-144. https://doi.org/10.33633/tc.v18i2.2268

Mardiati, K. S., \& Oktafianto. (2017). Sistem Pendukung Keputusan (Dss) Penerima Bantuan Rumah Tak Layak Huni (Rtlh) Pada Kecamatan Ambarawa Dengan Menggunakan Metode Analytical Hierarcy Process (Ahp). Prociding Kmsi, 5(1), 302308.

Ministry of Public Works and Public Housing of the Republic of Indonesia. (2020). Webinar Pembangunan Perumahan Dan Perkotaan Oleh Pemerintah Pusat Dan Dearah. Ministry of Public Works and Public Housing of the Republic of Indonesia.

Mursyidin, I. H., \& Rusdah. (2020). Sistem Pendukung Keputusan Pemilihan Penerima Bantuan Bedah Rumah Pemkab Tangerang Dengan Metode AHP dan SAW. Seminar Nasional Riset Dan Teknologi (SEMNAS RISTEK) 2020, 375-383.

Nalatissifa, H., \& Ramdhani, Y. (2020). Sistem Penunjang Keputusan Menggunakan Metode Topsis Untuk Menentukan Kelayakan Bantuan Rumah Tidak Layak Huni (RTLH). MATRIK : Jurnal Manajemen, Teknik Informatika Dan Rekayasa Komputer, 19(2), 246-256. https://doi.org/10.30812/matrik.v19i2.638

Puteri, A. D., \& Notobroto, H. B. (2017). Indikator Karakteristik Fisik Rumah Dominan dalam Penentuan Status Kemiskinan untuk Program Rehab Rumah tidak Layak Huni di Kabupaten Sidoarjo. Jurnal Biometrika Dan Kependudukan, 5(2), 107. https://doi.org/10.20473/jbk.v5i2.2016.107-116

Satria, B., \& Tambunan, L. (2020). Sistem Pendukung Keputusan Penerima Bantuan Rumah Layak Huni Menggunakan FMADM dan SAW. JOINTECS (Journal of Information Technology and Computer Science), 5(3), 167. https://doi.org/10.31328/jointecs.v5i3.1361

Sevrianda, I., \& Putri, D. Z. (2018). KARAKTERISTIK RUMAH TANGGA MISKIN PERKOTAAN DAN PEDESAAN DI SUMATERA BARAT. EcoGen, 1 (September), $1-26$.

Simatupang, F. J., \& Wuryandari, T. (2016). Klasifikasi Rumah Layak Huni Di Kabupaten Brebes Dengan Menggunakan Metode Learning Vector Quantization Dan Naive Bayes. Jurnal Gaussian, 5(1), 99-111. 
Statistics Indonesia. (2010). Statistics Indonesia 2010. Badan Statistik Indonesia.

Sundari, S. S., Agustin, Y. H., \& Sidiq, L. (2019). Pengembangan Sistem Pendukung Keputusan Pemilihan Penerima Bantuan Rehabilitasi Rumah Tidak Layak Huni Kabupaten Tasikmalaya. SENSITif, 1(1), 1299-1309.

Tumanggor, H., Haloho, M., Ramadhani, P., \& Darma Nasution, S. (2018). Penerapan Metode VIKOR Dalam Penentuan Penerima Dana Bantuan Rumah Tidak Layak Huni. Jurikom, 5(1), 71-78.

Yetri, M. (2020). Sistem Pendukung Keputusan Untuk Menentukan Penerima Bantuan RSRTLH Menggunakan metode Weight Sum Model (WSM) pada Desa Tanjung Garbus 1 Kecamatan Lubuk Pakam. Jurnal SAINTIKOM (Jurnal Sains Manajemen Informatika Dan Komputer), Vol.09(1). 